\title{
SEX OFFENSES: THE MEDICAL AND LEGAL IMPLICATIONS OF SEX VARIATIONS*
}

\author{
Kard M. Bowman† and Bernice Engle†
}

I

\section{INTERSEXUALITY}

\section{A. Genetic Sexual Determination}

When a new individual is formed, heredity and other factors may play a role in producing sexual malformations. ${ }^{1}$ Within the past few years, there has been a considerable breakthrough in our knowledge of human genetics, and findings that are in many ways quite revolutionary have given us new and valuable insights in this area and have even changed some of our basic ideas. This body of knowledge, however, is continuing to expand, so that currently-held views must be regarded as only tentative at best and subject to further change as additional discoveries are made.

The human body is composed of cells; these combine to form organs; these, in turn, combine to form systems, such as the reproductive, respiratory, and digestive systems; and these, then, combine to form the individual. Cells differ in structure and function, but all cells contain chromosomes. Thirty-three years after the problem of human chromosome number was considered to be solved-that is, forty-eight had generally been accepted as the number of chromosomes in every human cell, except the sperm and the ovum-investigators examining some human cells in 1956 were "surprised to find that the chromosome number 46 predominated," a finding that has since been substantiated by others. ${ }^{3}$ These forty-six human chromosomes exist in the

* The authors wish to acknowledge helpful suggestions from the following: Dr. Roberto Escamilla, Dr. Gilbert S. Gordan, Jr., Dr. Hans Lisser, and Professor Curt Stern, sources for several references in this article.

† A.B. r909, D.Sc. r953, Washburn College; M.D. I913, University of California. Professor of Psychiatry, Emeritus, University of California School of Medicine, San Francisco. Formerly Medical Superintendent, Langley Porter Neuropsychiatric Institute; Head, California Sexual Deviation Research. Author, Personat Problems for Men and Women (1931). Contributor to psychiatric publications.

¥ A.B. I9I4, M.A. 1929, University of Kansas. Research Associate, Langley Porter Ncuropsychiatric Institute. Formerly Member, California Sexual Deviation Research; Member, Biomechanics Research Project, University of California Medical Center. Author, [with D. C. Lewis Nolan] WARtime Psxchintruy (1954); [with A. E. Bennett \& E. A. Hargrove] Psychiatry in General Hospitals (1956). Contributor to psychiatric publications.

1 The explanation that follows has been simplified to facilitate comprehension by the nonmedical specialist. For more detailed treatment of the subject, see Richard Goldschmidt, Theoretical Genetics 6, 424 (I955); S. Leonard Simpson, A. Stuart Mason \& G. I. M. Sawyer, Major Endocrine Disordens 294 (1959); Jost, Embryonic Sexual Differentiation (Morphology, Physiology, Abnormalities), in H. W. Jones \& W. W. Scott (Eds.), Hermaphroditism, Genital Anomalies and Related Endoctine DisORDERs I5 (1958); Ford \& Hamerton, The Chromosomes in Man, I78 NATURE 1020 (1956); Stern, The Chromosomes of Man, iI AM. J. HuMan Genetics 301 (1959).

${ }^{2} \mathrm{~T}$ jio and Levan, quoted by Stern, supra note $\mathrm{I}$, at 302.

${ }^{3}$ Ford, Jacobs \& Lajtha, Human Somatic Chromosomes, 181 NATune 1565 (1958). 
form of twenty-three pairs. Ordinarily, in the female, the twenty-third pair of cells consists of two $X$ chromosomes; in the male, however, the last pair consists of an $X$ and a $Y$ chromosome.

A new individual is conceived when two germ (sex) cells-an ovum from the female and a sperm from the male-unite. Each of these two germ cells is formed by the process of meiosis, or reduction division, in which the germ cell, which initially contained forty-six chromosomes, goes through various dividing processes until it has only twenty-three chromosomes, or half its original number. Each normal ovum contains an $X$ chromosome, and each normal sperm contains an $X$ or a $Y$ chromosome in equal proportions. Ordinarily, when a sperm containing an $X$ chromosome unites with an ovum, the zygote (fertilized ovum) will contain an $X X$ pair of chromosomes and will develop as a female. If the sperm contains a $Y$ chromosome, the zygote will contain an $X Y$ pair of chromosomes and will develop as a male. There has been a great deal of controversy about the roles of the $X$ and the $Y$ chromosomes in determining sex-whether female sex is determined by two $X$ chromosomes or by the lack of a $Y$, or whether male sex is determined by another pair of chromosomes called the $Z$ somatosomes. On the basis of recent findings, ${ }^{4}$ however, "it has now been established, in Man and the mouse, that the $Y$ chromosome determines maleness."

The developing embryo remains sexually undifferentiated for about forty-two days. ${ }^{6}$ Normal sex differentiation, which commences shortly thereafter, is determined at the time of conception by genetic sex. ${ }^{7}$ Since both the female and male gonads (primary sex glands) originate from an identical primitive gonad, its cortex (outer layer) can develop into an ovary in the female, or its medulla (center) can develop into a testis in the male. During this early stage, at about the fifth or sixth week, two sets of ducts, Wolff's and Müller's, also appear in the embryo. The former can develop into the sperm duct, consisting of the epididymis, vas deferens, and seminal vesicle in the male, or the latter can develop into the fallopian tubes, uterus, and upper vagina in the female. At about nine weeks in the development of the normal male embryo, and slightly later in the female, the appropriate duct continues to develop and the other one retrogresses. Sex differences of the embryo's external genitals are recognizable at about two months, ${ }^{8}$ and this development ordinarily is well underway at three months in the female fetus and at four months in the male. ${ }^{8}$

\footnotetext{
- Jacobs \& Strong, A Case of Human Intersexuality Having a Possible XXY Sex-Determining Mechanism, 183 Nature 302 (1959); Welshons \& Russell, The Y-Chromosome as the Bearer of Male Determining Factors in the Mouse, 45 NaT'L Acad. Scr. Proc. 560 (1959).

"Stern, supra note $I$, at $3 I \mathrm{I}$.

${ }^{-}$Grumbach \& Barr, Nuclear Sex in Sexual Anomalies, in 14 G. Pincus (Ed.), Recent Progress in Hormone Research 255 (1958).

${ }^{7}$ Grumbach, The Sex Chromatin Pattern and Human Sexual Anomalies, in G. Gordan (Ed.), YEAR Book of ENDOCRINoloGX 28r (I959).

${ }^{-8}$ Grumbach \& Barr, supra note 6 , at $27 x$.

- Jost, supra note $\mathrm{r}$, at 33 .
} 
Several factors can interfere with normal sexual development. On a genetic basis, a defect in the germ plasm may cause anomalies, some of which are manifested as early as the second or third month of gestation. Thus, for example, a gene inherited from the mother may cause hyperfunction of the adrenal gland in the fetus. Certain other factors, such as German measles, x-ray or hormone treatment, and ovarian tumors of the pregnant woman may also affect fetal development. After birth, too, several poorly understood conditions may produce abnormalities. Thus, the child may be sexually precocious or retarded. Or abnormal hormonal conditions may cause a partial transformation from one sex into the other-as, for example, in virilism in the young girl. Or the individual may exhibit some of the characteristics of both sexes, so that it is difficult to decide to which he or she actually belongs-the socalled pseudohermaphrodite. Or the individual may be born with functioning gonads of both sexes-the true hermaphrodite, who, however, is never a fully developed person of either sex.

Accordingly, attempts have been made to discover some simple absolute criteria by which the sex of an individual may genetically be determined. In the course of this search, a special material called the chromatin mass has been found in the nuclei of normal female cells that will absorb a dye visible under microscopic examination in forty or more per cent of the cells, with an average of seventy-two per cent in any one series. ${ }^{10}$ This chromatin mass is found in few or no nuclei of normal male cells, depending on the tissue examined. If this chromatin mass is found, the cells are called chromatin-positive; if no chromatin mass is found after examination of at least Ioo cells, the cells are called chromatin-negative. ${ }^{11}$ Another test that has attracted some attention is based on the presence of a drumstick-shaped mass in the nuclei of some polymorphonuclear leukocytes (white blood cells), which supposedly is found only in normal female cells. But recent studies have thrown considerable doubt on its reliability in determining the sex chromatin patterns in other tissues. ${ }^{12}$ The most reliable test of genetic sex is the actual viewing of the chromosomes-a very difficult procedure.

\section{B. Sexual Anomalies}

\section{True hermaphroditism}

The misidentification of the sex of a newborn infant is most commonly attributable to the fact that the individual is either a true hermaphrodite or a pseudohermaphrodite. ${ }^{13}$ In true hermaphroditism, the individual has both functioning testicular and functioning ovarian tissue. He may have (I) either one or two gonads with functioning testicular and ovarian tissue (ovotestis), (2) an ovotestis on one

\footnotetext{
${ }^{10}$ Grumbach \& Barr, Nuclear Sex in Sexual Anomalies, in 14 G. Pincus (Ed.), Recent Procress in Hormone Research 255, 257 (I958).

${ }_{11}$ Moore, Cytological Diagnosis of Chromosomal Sex in Man, 29 U. Manitoba MED. J. 35 (1957-58).

12 Grumbach, The Sex Chromatin Pattern and Human Sexual Anomalies, in G. Gordan (Ed.), Year BOOK OF ENDOCRINOLOGY 281, 282 (1959).

${ }^{13}$ True hermaphroditism is defined by a few to mean that the individual has active sperm and egg cells. To the knowledge of the writers, no such case has ever been reported.
} 
side and an ovary or testis on the other, or (3) a testis on one side and an ovary on the other. ${ }^{14}$

The true hermaphrodite may be predominantly male or predominantly female, and he may have the rudiments or the fully developed internal and external genitals of both sexes. ${ }^{15}$ There may be a shortened penis with an abnormally placed urethral opening, usually on the underside at a varying distance from the tip (hypospadias), although it may be thought of at times as an enlarged clitoris with an urethral opening at its base. A rudimentary vagina and uterus may be present, although the orifice may be closed. There may be a scrotum and a testis may have even descended into it, although frequently it is bifurcated and the gonads are undescended. A report of two true hermaphrodite children in one family and other similar reports support genetic theories about the cause of this condition. ${ }^{\mathbf{1 6}}$

The true hermaphrodite is not clearly of one sex or the other. Historically; in many countries, such individuals were allowed to decide to which sex they wished to belong and then were forced to adhere to this decision. The common-sense way of dealing with this problem, however, is for a physician to consult with the parents to decide which physical and psychic sex the individual resembles more closely and then, by surgery and endocrine treatment (administration of sex hormones), help the individual develop as far as possible as a member of that sex. ${ }^{17}$

\section{Female pseudohermaphroditism}

Pseudohermaphroditism, a condition in which the individual has the gonads of one sex but seemingly has the external genitals and other physical characteristics of the opposite sex, is a product of a number of still little-understood factors. More is known about female pseudohermaphroditism, in which a female with ovaries exhibits some male characteristics. ${ }^{18}$ The most common cause of this condition is hyperdevelopment of the fetal adrenal cortex, which produces an excessive secretion of androgens (the so-called male sex hormones). Another cause, already mentioned, is a hormone-producing ovarian tumor in the mother, who transmits her excess androgens to the fetus. Endocrine treatment of the mother during pregnancy; too, may result in masculinization of the fetus for the same reason. And finally, the fetus itself, for unknown reasons, may not develop normal sex organs.

Female pseudohermaphroditism due to adrenal cortex hyperactivity results in the progressive virilization of the female. Since the virilizing process progresses at different rates in different individuals, the infant may or may not be recognized as

16 Frank Hinatan, Principles and Practice of Urology 134 (1935).

${ }^{15}$ Hans Lisser \& Roberto Escamilla, Atlas of Clinical Endocrinology 333 (I957).

${ }^{10}$ Milner, Garlick, Fink \& Stein, True Hermaphrodite Siblings, 79 J. URoL. I003 (I958); Brewer, Jones \& Culver, True Hermaphroditism, 148 A.M.A.J. 431 (I952). See also Clayton, Smith \& Rosenberg, Familial True Hermaphroditism in Pre- and Postpuberal Genetic Females, 18 J. Clin. Endocrin. \& Metab. 1349 (1958).

${ }^{17}$ See notes $42-45$ infra and accompanying text.

${ }^{18}$ Grumbach, The Sex Chromatin Pattern and Human Sexual Anomalies, in G. Gordan (Ed.), Year Book of ENDOCRINOLOGY 281, 284 (1959). 
a female at birth. As virilization proceeds, however, the clitoris enlarges and comes to resemble a penis; body hair appears early, and at puberty, the voice deepens and a beard develops, the body build becomes muscular and masculinized, and such feminine characteristics as breast development and menstruation never appear. ${ }^{10} \mathrm{Re}-$ ports of congenital virilization due to adrenal cortex hyperactivity in identical twins support genetic theories about the cause of this condition. ${ }^{20}$

For a number of years, female pseudohermaphrodites were treated by operation and endocrine therapy to help them develop into as complete males as possible. ${ }^{21}$ With the discovery of cortisone, which halts the hyperactivity of the adrenal cortex, however, virilism can be arrested if treated in its early stages and the individual can develop into an essentially normal female. ${ }^{22}$

\section{Male pseudohermaphroditism}

In male pseudohermaphroditism, sometimes called testicular feminization, individuals with testes may develop feminine characteristics in varying degrees. In the mildest cases, a small penis is present and some degree of breast development occurs at puberty. ${ }^{23}$ In the extreme cases, however, the individual appears as a normal, but nonmenstruating, woman -often being raised as such ${ }^{24}$-with well-developed breasts, female external genitals, a vaginal canal (usually a blind pouch), and frequently, sperm ducts. This condition is produced by a hypersecretion of estrogen (the socalled female hormone) by the testes in the abdominal cavity. Its high familial incidence, in both the mild and the extreme form, suggests that this is a geneticallydetermined disorder. ${ }^{25}$

Treatment of male pseudohermaphroditism will depend on a variety of factors. Some authorities recommend removal of the gonads, since in about fifteen per cent of the cases, they become malignant. ${ }^{26}$ In mild cases, if the individual is not very feminized and has been raised as a male, castration is supplemented by endocrine treatment in order to increase masculinization. In extreme cases of essentially feminine individuals who have been raised as females and who wish to remain such, however, attempts should be made by surgery and endocrine treatment to aid de-

${ }^{19}$ Lisser \& Escamilla, op. cit. supra note 15 , at 240.

${ }^{20}$ Schneeberg, Steinberg, Malen, Chernoff \& Yap, Congenital Virilizing Adrenal Hyperplasia in Identical Twins, ig J. Cinn. Endocrin. \& Metab. 203 (1959).

${ }^{21}$ Hinman, Advisability of Surgical Reversal of Sex in Female Pseudohermaphroditism, I46 A.M.A.J. 423 (I95I).

${ }^{23}$ Lisser \& Escamilla, op. cit. stupra note I5, at 246.

. ${ }^{23}$ Grumbach \& Barr, Nuclear Sex in Sexual Anomalies, in $\mathrm{r}_{4}$ G. Pincus (Ed.), Recent Proontss iN HoRMONE RESEARCh 255, 292 (I958).

${ }^{26}$ Goldberg \& Maxwell, Male Pseudohermaphroditism Proved by Surgical Exploration and Microscopic Examination: A Case Report with Speculations Concerning Pathogenesis, 8 J. Clis. Endocnin. \& MetAB. 367 (1948).

${ }^{25}$ Morris, The Syndrome of Testicular Feminization in Male Psendohermaphrodites, 65 AM. J. Obstet. \& Grnecol. II92 (1953). See also Jacobs, Baikie, Court Brown, Forrest, Hugh, Stewart \& Lennox, Chromosomal Sex in the Syndrome of Testicular Feminisation, 2 LANCET 591 (1959).

${ }^{20}$ Morris, supra note 25. See also Wachstein \& Scorza, Male Pseidohermaphroditism: A Type Shouing Female Habitus, Absence of Uterus and Male Gonads Often Associated with Testicular Tubular Adenoma: Report of a Case and Review of the Literature, 21 AM. J. Cirs. Patr. Ir (I95I). 
velopment into as normal a female as possible. Although some question might conceivably be raised about the legality of this latter course, no judicial decisions in point have been found. In any event, however, common sense and good medicine would seem to indicate that the individual's wishes be considered and that measures be taken to enable him to be as normal a person of the desired sex as possible.

\section{Klinefelter's and Turner's syndromes}

Two other conditions may cause some question concerning an individual's sex, and the possibility of true sex reversal has been raised. The well-recognized manifestations of Klinefelter's and Turner's syndromes are examples of what used to be considered true sex reversal. Only within the last year, owing to an improved method for viewing chromosomes, has it been possible better to understand the basis of these syndromes. It is now known that the chromatin-positive form of Klinefelter's syndrome and the chromatin-negative form of Turner's syndrome result from chromosomal abnormalities. In the few cases extensively studied so far, chromatin-positive individuals with Klinefelter's syndrome have been found to have forty-seven instead of the normal forty-six chromosomes, and those with chromatin-negative Turner's syndrome have been found to have forty-five chromosomes. ${ }^{27}$

In Klinefelter's syndrome, the individual is a sterile male, although in four cases of the chromatin-positive form, very small numbers of spermatozoa have been found in the seminal fluid. ${ }^{88}$ Frequently, he develops gynecomastia (breast enlargement), with breasts not unlike those of a woman, and his testes are small. He is commonly able to have a normal sex life, however; in fact, some individuals with this syndrome have been discovered only because they sought medical advice concerning their infertility.

Since about seventy per cent of those afflicted with Klinefelter's syndrome are chromatin-positive, ${ }^{29}$ it was hypothesized that they had begun to develop as females, but had been changed during intrauterine life to imperfect males. But the most recent studies indicate that this syndrome rather results from the chromosomal variation already mentioned; the afflicted individual has forty-seven chromosomes, and instead of having an $X Y$ sex chromosome pair as the twenty-third pair, he has an $X X Y$ combination. In the light of this finding, that this syndrome in most cases is caused by an additional $X$ chromosome, the individual with this condition is now no longer considered as an example of sex reversal, but as one who has always been a male. He has not developed perfectly because of a chromosomal abnormality and can be compared to a person born with an abnormality as a harelip or a cleft palate.

Legally, there should be no question that such an individual is a male; and psycho-

${ }^{37}$ Ford, Chromosome Unbalance and Abnormal Development in Man, 6 NEw ScIENTIST 405 (1959).

${ }^{28}$ Ferguson-Smith, Lennox, Mack \& Stewart, Klinefelter's Syndrome, Frequency and Testicular Morphology in Relation to Nuclear Sex, 2 LANCET 167 (1957). See also Stewart, Ferguson-Smith, Lennox \& Mack, Klinefelter's Syndrome: Genetic Studies, 2 LANCET II7 (1958).

${ }^{20}$ Grumbach \& Barr, Nuclear Sex in Sexzal Anomalies, in 14 G. Pincus (ED.), Recent Progress in HORMONE RESEARCH 255, 265 (I958). 
logically, it is important for the individual and others to consider him as such. Treatment sometimes consists of a mastectomy (removal of breast tissue) and endocrine treatment, since the testes are frequently underdeveloped.

Turner's syndrome is a condition found in females whose ovaries have failed to develop and who fail to menstruate or to develop secondary sex characteristics (breast development and pubic hair growth). The syndrome is often associated with other congenital abnormalities such as small stature, malformation of fingers and toes, heart disease, webbed (short thick) neck, and others. These females are always sterile.

A chromatin-negative pattern for about eighty per cent of such cases has been estimated. ${ }^{30}$ The condition has been described as the inverse situation of Klinefelter's syndrome: the individuals are essentially female, and yet the majority lack sex chromatin. It is stated that the chromosomal makeup in those afflicted with chromatin-negative Turner's syndrome is probably $X O$ rather than $X X$; the individual lacks a chromosome, and instead of having the normal complement of $X X$, she has only one $X$. Development is complicated by abnormal sex differentiation in the developing embryo. It has been emphasized, however, that "the XO patient should not be referred to as an instance of 'sex reversal,' as a 'chromosomal male,' or as a 'genetic male': she is a female, with an abnormal genotype."31

Physiologically, the main treatment is the cyclic administration of estrogens to stimulate the development of secondary sex characteristics and to produce uterine bleeding resembling menstruation. A few individuals with this condition have spontaneously menstruated, but most do not.

Klinefelter's and Turner's syndromes should be regarded as examples of imperfectly formed males and females, respectively, and those afflicted with them should be looked upon as true members of their sexes, not as sex transformations. There is no law regarding these conditions, as far as can be determined.

\section{Metafemale}

Another condition caused by a chromosomal abnormality only recently identified in a woman is that of the so-called "superfemale," which also occurs in the fruit fly. In the reported case, the thirty-five-year-old woman was sexually underdeveloped, had forty-seven chromosomes, and an $X X X$ sex chromosome pattern. She had stopped menstruating at age nineteen, had infantile external genitals, underdeveloped breasts, and a high (seventy-one per cent) proportion of chromatin-positive cells. In addition, she was of below average intelligence. ${ }^{32}$ It has been suggested that the term "super female" has been inappropriate when applied to the fruit fly and is now

\footnotetext{
${ }^{30} I d$. at 278 .

${ }^{31}$ Ford, Jones, Polani, De Almeida \& Briggs, $A$ Sex-Chromosome Anomaly in a Case of Gonadal Dygenesis (Turner's Syndrome), I LANCET 7II (1959).

${ }_{32}$ Jacobs, Baikie, Court Brown, MacGregor, MacLean \& Harnden, Evidence for the Existence of the Human "Super Female," 2 LANCET 423 (1959); Human Chromosomal Abnormalities, 2 LANCET 448 (1959).
} 
inappropriate when applied to the human because of its erroneous connotations. It has been proposed that the term "metafemale" (meta = beyond) be used instead in both the human and the fruit fly, since it would not only describe the appearance of the afflicted individual as beyond normal, but would avoid the implication that an. $X X X$ individual is at least genetically more female than an $X X$ individual. $^{\mathbf{3 3}}$

\section{Sexual precocity}

"True" sexual precocity has been described in a little girl as when she "has. developed into a woman, with adult secondary sex characteristics and periodic menstruation," and in a little boy as when he "has the appearance of a man, both as to the external genitalia and as to the secondary attributes of beard growth and pitch of voice."34 The age below which puberty is considered precocious has been defined as nine or ten for both sexes, since girls in North America reach puberty between nine and sixteen years of age, and most boys, between ten and seventeen years of age. The cause in most cases is unknown, and the condition is referred to as. idiopathic, or a primary disease, a term used in medicine to indicate ignorance of a. cause. Hereditary factors and brain (hypothalamic) tumors can produce sexual. precocity in both sexes; other known causes are tumors of the ovary in girls and tumors of the testis, adrenal cortex, or the pineal (a small gland near the central part. of the brain) in boys.

Sexually precocious little girls grow rapidly and early develop breasts, sexual. hair, and mature internal and external genitals. ${ }^{35}$ They may have some vaginal bleeding at age six months, and at as early as five years of age, they may menstruateand ovulate (produce ova or germ cells). One of the most famous cases on record is that of a Peruvian girl who began menstruating at eight months and who gave birth by Caesarean section at five-and-a-half years of age, to a six-pound boy.6= Most of these girls do not seem to be overly interested in sex, and a series of case histories indicates that, by and large, their sex drive seems to be the same as that for other girls of the same age. ${ }^{37}$ As they mature, they become normal individuals. who have simply been precocious in their sexual development; and as adults, they are no different from other women.

In boys as in girls, rapid body growth occurs early, sexual hair develops, external. genitals achieve adult proportion, the voice becomes deep and masculine, and acne is fairly common. ${ }^{38}$ Erections and nocturnal emissions occur, and spermatogenesis. (production of sperm) may or may not be present. Most reports state that these

${ }^{33}$ Stern, Use of the Term "Super-female," 2 LANCET 1088 (1959).

${ }^{34}$ Lisser \& Reilly, The Gonads, in G. Gordan \& H. Lisser (Eds.), Endocrinology in Clinical Practice 255 (1953).

${ }^{36}$ Hans Lisser \& Roberto Escamilla, Atlas of Clinical Endocrinology 34 i (1957).

${ }^{30}$ Escomel, cited by Lisser \& Reilly, The Gonads, in G. Gondan \& H. Lisser (Eds.), Endocrunology in Clinical Practice 255, 257 (I953).

${ }^{37}$ Hampson \& Money, Idiopathic Sexual Precocity in the Female: Report of Three Cases, I7 Psychosom. Med. 66 (1955).

${ }^{3 a}$ Lisser \& Reilly, The Gonads, in G. Gordan \& H. Lisser (Eds.), Endocrinozogy in Clinicat. Practice 255, 261 (1953). 
children are not hypersexual in the sense that they are sexually aggressive and constantly seeking sex partners or that they masturbate excessively. ${ }^{\mathbf{3 0}}$

Raising these children in a normal atmosphere is sometimes very difficult. The sexually precocious boys become objects of curiosity for all the rest of the children. Mothers of little girls are likely to become terrified at the idea of their daughters' exposure to a "sex fiend." The public school teacher may be very disturbed at having to work with a small boy who is apparently a sexual adult. The fact that these individuals grow rapidly and mature sexually causes everyone to treat them as though they were much older than they actually are, thereby creating many difficult problems for them. The following case illustrates some of these problems.

A fraternal twin boy, with a normal sister, began his sexual development early. At one year, his genitals were enlarged; at twenty-six months, pubic hair was noted; and at two and a half years of age, both penis and testes were overdeveloped. At thirty-two months of age, he was admitted to a university hospital for a two-week study, at which time he was found to be well above average in height and weight for a boy of his age, and, apart from his sexual precocity (for which no cause could be determined), physiologically normal, although below average mentally.

His father had left the home when the boy was five years old, and his mother felt she could not handle him because of his aggressiveness and strength. He had been accused of making sexual advances, although the episodes involved only his being discovered in an alley lifting up the dresses of two girls his own age and a vague, unsubstantiated reference to his having done or said something regarding a neighbor's breasts. Because of neighborhood pressure, his mother built a fence around a four-foot by ten-foot yard, in which she confined the boy for six months. She sought help from several social agencies, and when the school refused to keep the boy because of his boisterousness, the mother applied to the court for his commitment to an institution, which petition was granted.

At the age of six and a half, the patient was again found to be physically normal except for his sexual precocity and his bone and hormonal ages, which were well into adolescence. He was given psychological tests, and although his IQ was still substantially below normal, the examiner emphasized that his performance in some areas was quite good and that his retardation could be a result of his earlier enforced isolation rather than true mental deficiency. While he was in the institution, he learned to write his name, a skill his normal twin-sister had not yet acquired.

The boy, a lively, boisterous, and sometimes destructive child, improved in his relationships with the doctors and other personnel, probably as the result of psychotherapy. Even at the hospital, however, he was sometimes treated more like an adolescent than a six-and-a-half year old boy. After some time, his mother decided to take him home to live with her, his aunt, and his sister. At the latest report, he was attending school, apparently with success.

${ }^{39}$ Money \& Hampson, Idiopathic Sexual Precocity in the Male: Report of a Case, I7 PsYchosom. Med. I (1955). 
It must be emphasized that while sexually precocious children may look like adolescents, they are, nevertheless, still children and must be treated as much like other children as possible. They are not usually oversexed, but merely prematurely developed; nor are they sex maniacs. Although they are larger than other children of their own age while they are young, by puberty, their growth will have stopped because of early calcification of growth centers in their arms and legs, which are short in relation to their bodies. By about the age of eighteen, they are actually shorter than most boys and girls of their age. If such children are handled intelligently and sympathetically during the period of their sexual precocity, they will probably become normal, although short, adults. The importance of such treatment cannot be overemphasized.

\section{Eunuchoidism}

A group of individuals, both male and female, are imperfectly developed sexually and at puberty, fail to develop the normal secondary attributes of their own sex. One of the most frequent causes of this condition is a failure of the pituitary gland to secrete the sex-stimulating hormones. Another cause is the failure of the gonads to function normally. The condition occurs occasionally in families, but in some cases, it is not known whether the defect was of the gonads or of the pituitary gland.

In males afflicted with this condition, the penis is commonly very small, and many show marked growth in their long bones (arms and legs), so that a form of gigantism occurs. In females, the infantile vagina and uterus fail to mature, other sex characteristics do not develop at puberty, and many are tall and continue to grow beyond the normal age, although not demonstrating gigantism. ${ }^{40}$

Five instances of eunuchoidism in two families have been reported in which endocrine treatment was successful in inducing genital development and the development of secondary sex characteristics. ${ }^{41}$ In girls as well as boys, almost normal maturation can occur, although infertility persists if the condition is severe.

\section{Criteria for Sex Determination}

Seven variables affecting sex determination have been defined by some authorities. $^{42}$ First, there is chromosomal sex, determined by examination of the actual chromosomes or by the chromatin mass test, described above, which presumably indicates how the individual originally started out. Studies of twelve true hermaphrodites show that eight had a chromatin-positive and four a chromatinnegative pattern.

The second criterion is gonadal sex. Some might assume that if an individual had

“ Hans Lisser \& Roberto Escamilla, Atras of Clinical Endocrinology 35 (1957).

${ }^{41}$ Biben \& Gordan; Familial Hypogonadotrophic Eunuchoidism, 15 J. Clin. Endocrin. \& Metab. 93 I (1955).

"Money, Hampson \& Hampson, Hermaphroditism: Recommendations Concerning Assignment of Sex, Change of Sex, and Psychologic Management, 97 Burx. JoHns Hopkins Hosp. 284 (1955). 
gonads that were either testes or ovaries, this would be a definitive way of diagnosing sex.

That this is not a completely adequate or satisfactory method, however, is shown by consideration of the third criterion, hormonal sex. In certain females, the ovaries are inert, but the adrenal gland produces androgens that masculinize the individual (female pseudohermaphroditism); and in certain males, the testes produce excessive estrogens that feminize the individual (male pseudohermaphroditism). Obviously, therefore, the mere presence of ovaries or testes cannot be the ultimate criterion; the role of the adrenal gland in producing both estrogens and androgens must also be considered.

The fourth criterion is the nature of the internal accessory organs-the uterus in the female and the prostate gland in the male. These fail to mature without medical intervention in many intersexed individuals. Since they are necessary for reproduction, their presence is useful in determining sex assignment, but not as important as some of the other criteria mentioned.

The appearance of the external genitals is the fifth criterion. Obviously, this is the basis on which sex is most commonly assigned. Where the external genitals are not completely developed, it is now possible in many cases to effect a correction by surgery or by administration of endocrine substances, so that the individual will appear to be a normal individual of the assigned sex and thus escape many accompanying emotional problems.

Assigned sex and rearing is the sixth criterion. Assigned sex is the official decision as to whether the infant is a boy or a girl; rearing is the manner in which the child is raised. Even though assigned one sex, however, the child may actually be raised more as a person of the opposite sex. Thus, a girl, when young, might be a tomboy and display masculine behavior that was approved, even though she was officially called a girl.

The seventh and last criterion is gender role, by which is meant all those things a person says or does to disclose himself or herself as having the status of boy or man, girl or woman, respectively. It includes, but is not restricted to sexuality in the sense of eroticism.

It has been suggested that the three criteria of chomosomal, gonadal, and hormonal sex in themselves do not afford a satisfactory basis for determining the sex to be asssigned. Instead, it has been recommended that "in the case of neonatal and very young infant hermaphrodites ... sex be assigned primarily, though not exclusively on the basis of the external genitals and how well they lend themselves to surgical reconstruction in conformity with assigned sex," and possible endocrine treatment. And for older hermaphroditic infants, children, and adults, it has been recommended both that first consideration be given to how firmly established gender role is, and that sex changes be "scrupulously avoided, except in rare and carefully appraised instances." 43

${ }^{4}$ Ibid. 
Other authorities list six variables that affect sex determination: genetic (chromosomal), gonadal, endocrinological (hormonal), body habitus (appearance), genitalia, and secondary sex characteristics. ${ }^{44}$ Since these authorities emphasize the close correspondence between the psychological and the body sex, one may infer that if an individual conforms to four of the six equally weighted criteria for one sex, he should be assigned to that sex. There are, however, many criticisms of this method of sex assignation.

And finally, it has been stated that neither the somatic sex nor the early identification of the patient with one sex is all-important. "The essential criterion is the strength of the patient's identification with one sex or the other." 45

In the opinion of the writers, no law should be enacted regarding the sex determination of true hermaphrodites at the present time. The physician, in consultation with the family, should make the decision on the basis of medical knowledge and the wishes of the family if the individual is a young child. If old enough, the individual himself or herself should be consulted. Nor would legislation be helpful regarding the sex determination of pseudohermaphrodites. It is better to leave the law books uncluttered with specific statutes and to allow the physician freely to exercise his judgment, accepting or rejecting the suggested medical criteria.

\section{II}

\section{Sexual Deviation}

\section{A. Homosexuality}

Homosexuality is commonly defined as sexual attraction toward those of the same sex. The term covers the entire range of these erotic desires, from the highly sublimated ones to definite genital gratification. The terms, latent and overt, contrast desires, largely unconscious, with actual genital practice.

The Kinsey studies ${ }^{46}$ rate both male and female homosexuals along a seven-point scale, representing a balance between the homosexual and heterosexual aspects of an individual's history. The ratings, which depend on the individual's psychological reactions and on his or her amount of overt sexual experience, range from $o$, entirely heterosexual, and $I$, largely heterosexual, but with some homosexual history, to 5, largely homosexual, with some heterosexual history, and 6, entirely homosexual. The individual in the middle, at 3 , equally heterosexual and homosexual, can be termed "a true ambisexual."

Far more men than women indulge in some overt homosexual behavior, and this with greater frequency. The Kinsey studies revealed that only half as many females as males had had homosexual responses, that only about a third as many had reached

\footnotetext{
"Cappon, Ezrin \& Lynes, Psychosexual Identification (Psychogender) in the Intersexed, 4 CaN. Psychist. Ass's J. 90 (x959).

${ }^{45}$ Stoller \& Rosen, The Intersexed Patient, 9r Callf. Med. 26I (I959).

"Alfred C. Kinsey, Wardell B. Pomeroy \& Clide E. Martin, Sexual. Behavior in the Human Male (1948); Alfred C. Kinsey, Wardell B. Pomeroy, Clyde E. Martin \& Paul H. Gebeard, Sexual Behavior in the Human Feamale (1953).
} 
orgasm in homosexual contacts, and that males continued their homosexual activities for many more years than did females and were far more promiscuous.

Many male and female homosexuals, both with and without a history of heterosexual experience, act and feel like other males and females, nor do they overidentify themselves with the opposite sex. For example, many male homosexuals are athletes who have strong masculine interests. In another group are males who regard themselves as taking the female sexual role, whether or not they assume other feminine attributes. ${ }^{47}$

The causes of homosexuality are not understood. Some investigators regard the deviation as wholly or almost wholly constitutional and physiological, even though these aspects are not at present demonstrable. Others consider the deviation to be primarily psychic-one of retarded emotional development, or psychological conditioning within a family situation of parental rejection or reversal of the paternal and maternal roles.

Treatment with sex hormones has no effect on homosexuality, except for a possible psychological effect in the individual case. Administration of estrogens to males will decrease their sex drive, and administration of androgens to females will usually produce masculinization; but androgens in large doses will increase sex desire in the female, and in some cases in the male. Psychotherapy and psychoanalytic treatment have been suggested too, but very few improvements have been reported. It may, however, help some individuals with ambivalent drives to attain heterosexual adjustment, since they are not completely set against it; and it may help the homosexual to understand and accept his condition and to live with it, as Freud pointed out, although it does not alter his condition. In this sense, such treatment has had great value. Nevertheless, there is at present no clear-cut accepted medical solution to the problem.

The legal treatment of homosexuality, in this country and abroad, has been analyzed and discussed extensively in other articles in this symposium ${ }^{48}$ and elsewhere. ${ }^{49}$ Accordingly, the matter will not be dwelt upon at any length here. Perhaps it will suffice to observe that a more humane and rational future solution of the problem is portended by the American Law Institute's Model Penal Code, ${ }^{50}$ with whose general philosophy in this area and many of whose provisions the writers find themselves in accord. Such a solution would demand of both homosexual and heterosexual individuals the same standards of sexual behavior: (I) no force; (2) no corruption of the young; and (3) no abuse of public decency.

47 Bowman \& Engle, The Problem of Homosexuality, 39 J. Soc. HYGIENE 2 (I953).

${ }^{18}$ Ploscowe, Sex Offenses: The American Legal Context, supra pp. 217-24; Hall Williams, Sex Offenses: The British Experience, infra pp. 334-60; Stürup, Sex Offenses: The Scandinavian Experience, infra pp. $36 \mathrm{r}-75$.

"Dowman \& Engle, A Psychiatric Evaluation of Laws of Homosexuality, 29 TEMPLE L. Q. 273 (x956); Committee on Homosexual Offences and Prostitution, Report, CMND. No. 247 (1957); Eusrice Chesser, Live and Let Live (1958); Peter Wirdeblood, Against the Law (r959).

${ }^{50}$ Model Penal Code art. 207 ('Tent. Draft No. 4, 1955; Tent. Draft No. 9, 1959). 
B. Fetishism, Transvestism, and Transsexualism

Although, as the writers have pointed out elsewhere, ${ }^{\mathbf{5 1}}$ transvestism and transsexualism or complete inversion are interwoven with other sexual deviations, only fetishism will be discussed in this connection here.

\section{Fetishism}

Fetishism may be defined as a type of compulsive disorder, most usually found in males, in which an object or article largely replaces the sexual partner as a source of sexual gratification. The article or object is often associated with a beloved person, typically the mother, and it must be used-seen, touched, or smelled, in generalfor the sexual act to be gratifying. Common objects are female clothing-particularly underwear, stockings, shoes, coats, furs-and parts or organs of the human body. To date, no evidence links fetishism with any physiological process. Kinsey considered that both fetishism and transvestism depend upon the psychological conditioning "involved in most erotic responses," and that transvestism, especially, illustrates the fact that males are more liable and females less liable to be conditioned by psychological stimuli. ${ }^{52}$

In some cases, fetishism is essentially normal and fairly universal. As generally practiced, it is in its legal aspects a nuisance or minor type of crime-e.g., stealing female clothes from a clothes line. In a few cases, it has been associated with more serious crime, of which the Heirens case ${ }^{53}$ is an example. There, the patient, a seventeenyear-old college student, had stolen female underclothing as a fetish in childhood. Later, the excitement of burglary became his fetish, and if startled in the act of burglary, he killed at once. Convicted of twenty-five burglaries, one robbery, three murders, and one assault to commit murder, he received various sentences to run concurrently, three for life.

\section{Transuestism}

Transvestism, or cross-dressing, also found predominantly in males, may be defined as the compulsive desire of an individual to wear some or all of the clothing and to play at least a partial role of the opposite sex. It may amount largely to fetishism, as in the case of a man who dons under his suit a girdle or panties for reasons of sexual satisfaction. Some transvestites claim to have no homosexual desires and have never engaged in overt homosexual activity; they insist that they merely feel more comfortable and at ease in garments of the opposite sex than in their own clothing. Other transvestites vary from ambisexuality to complete homosexuality; and a few are what are commonly called cases of transsexualism or complete inversion.

\footnotetext{
¿1 Bowman \& Engle, Medicolegal Aspects of Transuestism, Ir3 AM. J. Psychiat. 583 (1957).

"alfred C. Kinsey, Wardell B. Pomeroy, Clyde E. Martin \& Paul H. Gebhard, Sexual Behavior IN THE HUMAN FeMate 679-81 (1953).

${ }^{53}$ Kennedy, Hoffman \& Haines, A Study of William Heirens, I04 AM. J. Psychiat. II3 (I947); Kennedy, Hoffman \& Haines, Psychiatric Study of William Heirens, 38 J. Crm. L. 311 (1947). See also Lucy Freeman, Before I KizL More (1955).
} 
Transvestism is not specifically forbidden by law, except as it may be connected with a crime of fraud or deceit, theft, or the like. But public opinion decries it, especially when practiced by men, and almost all state laws on disorderly conduct, vagrancy, or disturbance of the peace can be construed to cover it. Accordingly, some physicians issue to their transvestite patients and instruct them to carry certificates stating that for medicolegal reasons, they wear clothes of the opposite sex. While such a certificate may carry no weight with police, prosecutors, or judges, it may sometimes help; and in any event, it usually increases the patient's sense of security and well-being.

\section{Transsexualism}

The terms transsexualism or complete inversion or genuine transvestism indicate a condition in which an individual has an intense, usually obsessive, desire for a complete sexual transformation. The male transsexualist insists that he is psychologically a female and demands that his physical sex be made to correspond with his claimed psychosexual state. He may threaten and even commit suicide or self-mutilation. Such individuals are homosexual, but they deny homosexuality on the ground that they are actually persons of the opposite sex. Thus, a male patient explained that his soul and mentality were those of a woman, but God had given him a man's body.

As noted with respect to other manifestations of homosexuality, there is no clear evidence of a physiological basis for this condition. For example, in a recent study, five male transsexualists had the nuclei of "a typical male morphology" (these nuclei are now called chromatin-negative); and from this finding, it was, therefore, "inferred that these persons bear the male $X Y$ sex chromosome complex." ${ }^{54}$ Yct, one cannot call the condition purely psychological merely because a physiological causation cannot be demonstrated. Some investigators, for example, consider a constitutional predisposition essential, followed by adverse psychological conditioning and the respective syndromes.5 ${ }^{55}$ Perhaps within the next few years, following the present breakthrough in genetics, a whole series of physiological factors may be revealed.

Like all sexual deviations, at least those of which the law takes cognizance, transsexualism is far more common in men than in women. Quite well known, for example, is the case of George (Christine) Jorgensen, which attracted wide attention a few years ago. ${ }^{56}$ There, in brief, after two years of study by Danish physicians and accompanying hormonal treatment, a twenty-four-year-old man who desired sex transformation was surgically altered and issued papers by governmental authorities enabling him to appear publicly as a woman. After publication of this case,

\footnotetext{
¿ Barr \& Hobbs, Chromosomal Sex in Transuestites, I LANcet I109 (1954); Rabach \& Nedoma, Scx Chromatin and Sexual Behavior, 20 Psychosom. Med. 55 (1958).

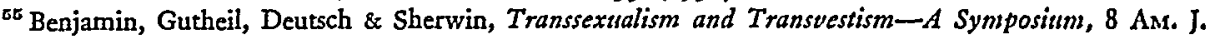
PsYchother. 219 (1954).

${ }^{5 e}$ Hamburger, Stürup \& Dahl-Iversen, Transvestism, Hormonal, Psychiatric, and Strgical Treatment, I52 A.M.A.J. 39I (I953).
} 
the Danish physicians received requests for sex transformation from about 2,000 persons, of whom sixty were thought to be transsexualists: And these figures do not begin to approach the real number in the opinion of many investigators, who, from the biologic point of view, regard bisexuality, some types of homosexuality, and transvestism-transsexualism as stages along a continuum of sexual deviations, with so-called transsexualism as "the last consequence of a passive male or active female homosexuality."

Some physicians favor surgery in those patients who are inaccessible to psychotherapy. The conversion operations commonly consist of castration, penectomy, plastic transformation of the scrotum into labia-like formations, and possible construction of an artificial vagina. To those who object that physicians must not be constrained by the patient and made to satisfy his demands for treatment, it is urged that sex transformation surgery be analogized to leukotomy. Neither procedure should be dictated by juridical judgment alone, but should rather be preceded by and based upon thorough medicolegal investigation. "To help the transvestite, not to cure the transvestism, that is the question."

Clinical reports of about half a dozen female transsexualists have also appeared. These women are mostly interested in wearing male attire and taking jobs commonly filled by men. Usually such an individual lives as the husband of another woman. The intensity seen in male transsexualism is rare, however, and the treatment requested of the physician is usually less heroic.

After the notoriety of the Jorgensen case, Danish authorities refused to perform sexual transformation on males who were not Danish citizens of long standing. Conversion surgery has been performed in other European countries as well, however, and it would appear that even in Great Britain such an operation may be authorized in exceptional cases. ${ }^{58}$ But in this country, although such surgery is nowhere expressly forbidden by law, it is generally regarded as coming within the proscription of the mayhem statutes, which for want of a suitable modern law, have "been extended to include any willful disfigurings of the body."59 Nevertheless, surgeons will perform mastectomies alone without much reluctance, since these operations are often performed for cosmetic as well as therapeutic reasons.

There is also some uncertainty as to whether or not a change of name and civil status, which is permitted in some foreign countries, ${ }^{60}$ may legally be effected in the United States. A male upon whom conversion surgery had been performed in Mexico filed a petition for change of name and civil status in California; but when his out-of-state birth certificate could not be legally changed, the petition was denied. In another California case, however, a similar petition was granted; but the individual's birth certificate had been made out in the name of Baby $\mathrm{S}$ - and bore no

${ }^{67}$ Anchersen, Problems of Transvestism, I06 Acta Psychiat. ET Neurol. 249 (Supp. 1955).

${ }^{\mathrm{s}}$ Lukianowicz, Survey of Various Aspects of Transvestism in the Light of Our Present Knowledge, I 28 J. Nerv. \& MeNT. Dis. 36 (1959).

${ }^{00}$ Sherwin, The Legal Problem in Transuestism, 8 AM. J. Psychoтнer. 243 (1954).

${ }^{\circ}$ Lukianowicz, supra note 58. 
given name, and the county registrar was willing to change the stated sex and to fill in the new name. In still another case, only the change of name was granted, without reference to the person's sex. And in another, the individual was able to obtain a passport in his female role and characterization after his physician had written to the proper United States authorities "giving the full facts with [my] opinion and recommendation." ${ }^{\text {S1 }}$

Several instances of marriage between transsexualists and partners of the same sex have been reported. ${ }^{62}$ Late in 1959 , the Charles McLeod case gained some notoriety. Reared as a boy, he had served in the army, and after a series of operations (the first of which was performed illegally) and treatment in Denmark, he had taken the name of Charlotte McLeod. He returned to the United States, and at the age of thirty-four, he married a man in Miami, Florida, since the Florida marriage law does not require previously unmarried persons above the age of twenty-one to furnish a birth certificate. ${ }^{83}$

At present, many phases of the treatment of transsexualism are controversialmedically as well as legally-and no current solution is completely satisfactory. Existing laws are sufficiently flexible, however, probably to permit any satisfactory form of therapy to be practiced, if and when it is found.

ex Confidential personal communications to the writers.

"Horton \& Clarke, Transvestism or Eonism, 87 AM. J. Psychiat. I025 (I93I); Redmount, $A$ Case of a Female Transvestite with Marital and Criminal Complications, I4 J. Crin. \& ExPER. PsYchoparH. 95 (1953); Northrup, Transsexualism, Report of a Case, I A.M.A. Arch. Gen. Psychist. 332 (I959).

${ }^{3}$ Fla. Stat. ANN. $\$ 741.05$ (Supp. 1959); San Francisco Chronicle, Nov. 14, 1959, pp. 1, 4. 